\title{
Environmental and economic aspects of the exploitation of roads by the mining industry
}

\author{
Ludmila Boginska ${ }^{1,{ }^{*}}$, Olena Hasii ${ }^{2}$, Oksana Yurchenko ${ }^{1}$, and Viacheslav Shushkevych ${ }^{1}$ \\ ${ }^{1}$ Sumy National Agrarian University, 40021, Sumy, Herasym Kondratiev Str., 160, Ukraine \\ ${ }^{2}$ Poltava University of Economics and Trade, 36014, Poltava, Koval Str., 3, Ukraine
}

\begin{abstract}
The article is devoted to the development of the organizational and economic mechanism for the exploitation of roads by the mining industry. We support the statement that transport infrastructure is one of the most important components of any industry in the country's economy, including for the functioning of the mining industry. It connects multiple areas of the industry into a single whole. The requirements that must be considered when developing territories are given. The main requirement is to ensure weight control during freight transportation. It is considered that the greening of the processes of the device and road exploitation, which are used, including in the activities of mining enterprises, should ensure and keep the principles and conditions of environmental safety.
\end{abstract}

\section{Introduction}

The Law of Ukraine "On the National Security of Ukraine" determines that "national security is the protection of the vital interests of man and citizen, society and the state, which ensures the sustainable development of the society, timely detection, prevention and neutralization of real and potential threats to national interests" [1]. The interpretation of the definition of "environmental security" (assumes the prevention of environmental negatives) may fundamentally differ from the generally accepted definition of "national security".

The author's definition of the term "environmental safety of roads" is provided as external effects that determine the state of the environment during the functioning of the road system with a recipient structure of influence. In this case, the recipients are the elements of the environment (atmosphere, soil, water, biological resources) [2].

The issue of ensuring the environmental safety of transport systems and the road economy has been sufficiently studied [3-5], however, many aspects of the problem under consideration, especially the integrated assessment and optimization of the use of the economic mechanism to support the environmental safety of roads, in particular during the development of the mining industry, remain unresolved.

The problem of assessing the environmental and economic impact of the road system on the external environment is relevant in market conditions and is one of the priorities of scientific research, especially taking into account current trends in establishing and expanding the interaction of mining enterprises with other business entities in order to ensure the

*Corresponding author: Luda341@rambler.ru 
realization of their own strategic interests and environmental safety adjacent territories.

The purpose of this article is to study the process of exploitation of roads by the mining industry with its further optimization; development of practical recommendations for ensuring the environmental safety of roads serving the mining industry.

\section{Methodology}

The methodological basis of the article is a set of methods of scientific knowledge, methods, and techniques, general scientific principles that are used in the research process.

The methods of logical analysis (determining the interaction of roads with the environment); the dialectical method of cognition (in identifying the causal relationship of economic and environmental processes); analysis and synthesis (in identifying levels of the economic and environmental status of the transport system) are used. The system of information support for the processes of environmental and economic safety assessment has been developed for the diagnosis of the environmental and economic conditions of roads.

\section{Research results and discussion}

The mining industry has a technogenic impact on the geological environment, which is used by mankind in three directions:

- as a source of mineral raw materials necessary for the national economy;

- as a place of accumulation of production wastes;

- as a basis for the construction and operation of various engineering structures.

The road interacts with the environment more than other structures. In the environmental aspect, it can be considered not only as an engineering structure but also as an enterprise stretched out in one line, carrying out transport work and producing products in the form of transportation (Table 1).

Table 1. Transportation of goods by road by type of cargo for 2019 excluding transportation of goods by individuals-entrepreneurs (thousand tons) [6].

\begin{tabular}{|l|c|c|}
\hline \multicolumn{1}{|c|}{ Type of cargo } & In total & $\begin{array}{c}\text { Of which in } \\
\text { international traffic }\end{array}$ \\
\hline In total across Ukraine & 190041.19 & 10108.82 \\
\hline Of which the goods of the mining industry: & 76562.7 & 311.7 \\
\hline Coal and brown coal; crude oil and gas & 3704.78 & 24.69 \\
\hline $\begin{array}{l}\text { including: } \\
\text { - coal and brown coal }\end{array}$ & 3642.09 & 23.88 \\
\hline - crude oil & 51.07 & 0.44 \\
\hline - natural gas & 11.62 & 0.37 \\
\hline $\begin{array}{l}\text { Ores metal and other products of the mining industry } \\
\text { in quarrying: peat; uranium and thorium ores }\end{array}$ & 72857.62 & 287.01 \\
\hline $\begin{array}{l}\text { including: } \\
\text { - iron ores }\end{array}$ & 1156.71 & 0.45 \\
\hline $\begin{array}{l}\text { - non-ferrous metal ores (except for uranium and } \\
\text { thorium ores) }\end{array}$ & 423.59 & 63.73 \\
\hline $\begin{array}{l}\text { - mineral raw materials for the chemical industry } \\
\text { and production of natural fertilizers }\end{array}$ & 16.32 & 14.15 \\
\hline - salt & 24.03 & 9.29 \\
\hline $\begin{array}{l}\text { - stone, sand, gravel, clay, peat and other mining } \\
\text { and quarrying products not elsewhere classified }\end{array}$ & 71236.97 & 199.39 \\
\hline
\end{tabular}


In 2019, 190.0 million tons of cargo were transported in Ukraine by road, which is $41.5 \%$ more than in 2018. In particular, 10.1 million tons of cargo were transported in international traffic (38.9\% more). The largest share of cargo transported by road falls on the products of the mining industry and quarrying, such as stone, sand, gravel, clay, etc. 76.6 million tons [6]. Among all types of transportation of goods - road transport is the most popular. The road is the basis of the country's transport network, and motorization is a complex economic phenomenon, combining the efforts and interests of many departments. Based on this, there is a need to take into account and study the multifactorial impact of road transport, serving the needs of all industries, on the population and on all components of the environment. The fact that transport is one of the most important infrastructural components of the economy of any state is undeniable. It connects various territories and industries into a complete system. Therefore, the development of the transport network is considered an indispensable condition for improving the territorial organization and division of labor, industrial development, etc. It also applies to the mining industry, since it is an active user of transport services, exploiting heavy vehicles for transportation of mined minerals. The local and regional roads are the most commonly used by the mining industry.

The current normative documents in the country provide for the carriage of goods with a total mass (together with the mass of the vehicle) of not more than 40 tons. It should be noted that this norm does not differ from the norms provided for by European legislation [7]. Meanwhile, in the mining industry, an innovative fleet of trucks has been developed and put into operation, for example, consisting of BelAZ 75710 mining dump trucks with a carrying capacity of 496 tons and Liebherr T284 with a carrying capacity of 363 tons, American Bucyrus MT 6300AC truck with a carrying capacity of 363 tons and others. According to the data provided by the specialists of the State Road Research Institute, about $74 \%$ of roads were built under design axle loads of up to 6 tons and a total weight of no more than 24 tons, and $90 \%$ of roads in Ukraine require repair and construction work [2]. In this regard, the annual loss incurred to the road sector due to the destruction of roads caused by the movement of heavy vehicles is more than 2 billion hryvnias (about 0.08 billion in dollar terms). According to World Bank studies, the annual loss of the country's GDP due to the unsatisfactory condition of roads is $3-4 \%$ of the country's GDP [8].

In the context of the foregoing, an author's interpretation of the definition of "road fatigue" as a criterion for the condition of the road network is provided. It is proposed that the fatigue coefficient of roads be defined as the ratio of the total mass of heavy vehicles passing along the road to the design load of the road for the period of the standard repair cycle, taking into account the reduction in the life cycle of the road and the increase in the volume of repair work, which, in turn, leads to a decrease in the level of environmental safety roads:

$$
B=\frac{A}{L},
$$

where $B$ - the fatigue coefficient of the road; $A$ - mass of cargo, tons; $L$ - design load, tons.

When in the formula (1) $\mathrm{B} \geq 1$ - fatigue of the road takes place.

The authors considered a scientific and methodological approach, which, in contrast to existing approaches, takes into account the relationship between indicators of road fatigue and the growth of actual costs of repair work (influence factor) compared to the standard level and provides for the forecasting of additional capital investments in road repair, as well as an assessment environmental and economic damage depending on road fatigue.

We have proposed a scheme of regulation environmental balance in the presence of various phases of road life, as a criterion toolkit for analyzing and assessing the degree of their variation from environmental sustainability to destruction (Table 2). 
Table 2. Road life phases*.

\begin{tabular}{|c|c|c|c|c|}
\hline $\begin{array}{l}\text { Phase of road } \\
\text { condition }\end{array}$ & $\begin{array}{l}\text { The need } \\
\text { for repairs }\end{array}$ & $\begin{array}{l}\text { Loss of } \\
\text { roadbed }\end{array}$ & $\begin{array}{l}\text { Signs of } \\
\text { road } \\
\text { condition }\end{array}$ & Signs of phase \\
\hline Persistence & No need & No & Stability & $\begin{array}{l}\text { The road is in the state of } \\
\text { exploitation: the roadbed is not } \\
\text { damaged }\end{array}$ \\
\hline Admissibility & $\begin{array}{l}\text { Maintenan } \\
\text { ce work }\end{array}$ & $\begin{array}{l}10- \\
20 \%\end{array}$ & \multirow[b]{2}{*}{$\begin{array}{l}\text { Urgent } \\
\text { need for } \\
\text { repair }\end{array}$} & The need for patching \\
\hline $\begin{array}{l}\text { Threshold } \\
\text { admissibility }\end{array}$ & $\begin{array}{l}\text { Major } \\
\text { repair }\end{array}$ & $\begin{array}{l}50- \\
80 \%\end{array}$ & & $\begin{array}{l}\text { The need to strengthen the roadbed: } \\
\text { replacing the surface material (from } \\
\text { asphalt to concrete, increasing the } \\
\text { thickness of the roadbed) }\end{array}$ \\
\hline $\begin{array}{l}\text { Destruction } \\
\text { of the road }\end{array}$ & $\begin{array}{c}\text { The need for } \\
\text { road } \\
\text { construction }\end{array}$ & $\begin{array}{l}\text { up to } \\
100 \%\end{array}$ & $\begin{array}{l}\text { Loss of } \\
\text { roadbed }\end{array}$ & $\begin{array}{l}\text { Destruction of the road surface } \\
\text { and its foundation }\end{array}$ \\
\hline
\end{tabular}

*developed by authors

As well as any engineering structure, the road can provide the passage only of those loads and in the amount for which it was calculated during design. At the same time, there is a steady tendency towards an increase in the carrying capacity of cars (Table 3).

The movement of vehicles weighing more than 40 tons leads to a decrease in overhaul intervals and an increase in capital expenditures. Only $26 \%$ of Ukrainian roads are able to withstand heavy transport.

Table 3. Roads of Ukraine as of 01.01.2019 [6].

\begin{tabular}{|c|c|c|c|}
\hline Category of the road & I (state) & II-III (regional) & IV-V (local) \\
\hline Roadbed thickness, cm & 20 & $8-12$ & 5 \\
\hline Extent of roads, km & $4700(3 \%)$ & $43800(26 \%)$ & $121000(71 \%)$ \\
\hline Axle load, $\mathrm{t}$ & 11.5 & 10.6 & 7.0 \\
\hline Maximum standard weight of a car, $\mathrm{t}$ & 40 & 36 & 24 \\
\hline $\begin{array}{c}\text { The total weight of a modern loaded car } \\
\text { with an axle load of up to 16 tons (taken } \\
\begin{array}{c}\text { as the base) - (growth of the } \\
\text { international transit traffic by road) }\end{array}\end{array}$ & 60 & 60 & 60 \\
\hline Extreme fatigue of roads & $60 / 40=1.5$ & $60 / 36=1.67$ & $60 / 24=2.5$ \\
\hline
\end{tabular}

We made a correlation analysis of the dependence of the costs of over-planned road repairs on road fatigue (Fig. 1).

Correlation row is: an increase in road fatigue by an average of $2 \%$ leads to an increase in over-planned repairs by an average of $5 \%$ (data from 2014-2019 are applied: expenses for maintenance on roads in the Sumy Region (plan, fact (need)) [2].

The vast majority of Ukrainian roads are able to withstand a load of not more than 7 tons per axle. Along with this, $40 \%$ of the roads are already completely destroyed. They need major repairs practically "from scratch" (Table 4). The rest of the roads require immediate maintenance and strict adherence to the standard weight load on the axle.

At the present time weight control does not work in the country, and there are also imperfect norms in the current Ukrainian legislation. Based on this, and also guided by the experience of European countries, we proposed a set of administrative measures that will help preserve the road surface. In particular, it is necessary to introduce in Ukraine a European system of control over weight standards and payment for the use of roads for 
cargo transport with an axle load of more than 11.5 tons. These funds will be used for maintenance and road construction (trust funds). It is also necessary to strengthen the responsibility and increase fines for exceeding the weight norms by heavy-load cars and shift it to the industry that carries out this transportation of their products.

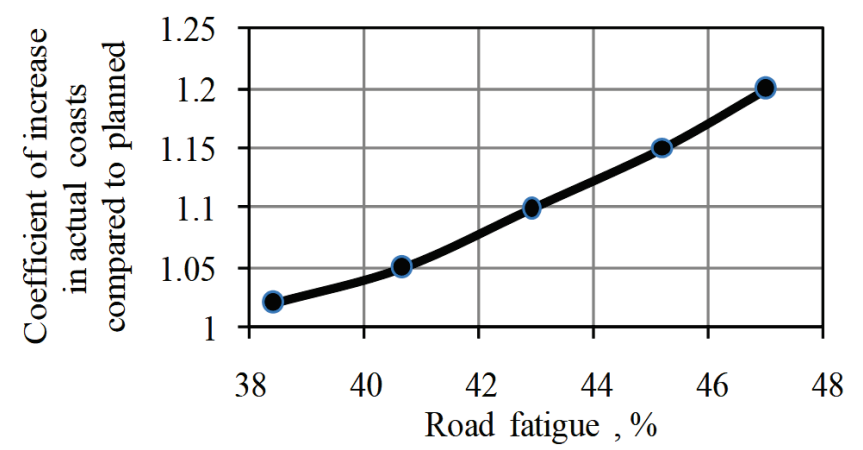

Fig. 1. The dependence of the costs of over-planned repairs of roads from the fatigue of the road.

Table 4. Differentiation of weight norms by road categories [2].

\begin{tabular}{|c|c|}
\hline Existing & Offered \\
\hline The entire road network & $\begin{array}{c}\text { Roads of state and regional } \\
\text { significance (49 thousand } \mathrm{km})\end{array}$ \\
\hline Total weight -40 tons & Total weight -40 tons \\
\hline- & Single axle load -11 tons \\
\hline- & Local roads (121 thousand km) \\
\hline- & Total weight -24 tons \\
\hline $\begin{array}{c}\text { If the specified weight parameters are exceeded, } \\
\text { the vehicle may take part in road traffic, provided } \\
\text { that appropriate permission is received from the } \\
\text { Ministry of Internal Affairs }\end{array}$ & $\begin{array}{c}\text { Cancellation of permissions to } \\
\text { participate in traffic in the case of } \\
\text { transportation of fissile goods, by } \\
\text { analogy with all other countries }\end{array}$ \\
\hline
\end{tabular}

Due to the large-scale destruction of the geological environment by economic activities of the mining industry, the problem of the maximum complete utilization of residual rock, slag, sludge, and other waste from the mining and processing industries for the needs of construction (including road), agriculture, etc., becomes more and more urgent.

Mineral extraction technologies cause the following types of environmental damages:

- geomechanical - cracking of rocks as a result of explosions, changing terrain, deforestation, deformation of the land surface;

- hydrological - changes in stocks, the mode of the movement, quality and level of groundwater, removal of harmful substances into water bodies from the surface and bowels of the Earth;

- chemical - changes in the composition and properties of the atmosphere and hydrosphere (acidification, salinization, water, and air pollution);

- physical and mechanical - environmental pollution by dust, changes in the properties of land cover, etc.;

- noise pollution and soil vibration [9].

In order to avoid the destruction of the geological environment during the construction of roads, it is necessary to carry out the whole range of engineering and geological researches, so that, depending on the specific engineering and geological conditions, it is possible to correctly determine the nature of the foundation, roadbed and other features of 
the designed structures.

We have developed an algorithm for the greening of the process of construction and exploitation of roads, including in the mining industry. The proposed model will create a sustainable base for the development of enterprises of the type "science-developmentimplementation-environmental road safety" (Fig. 2).

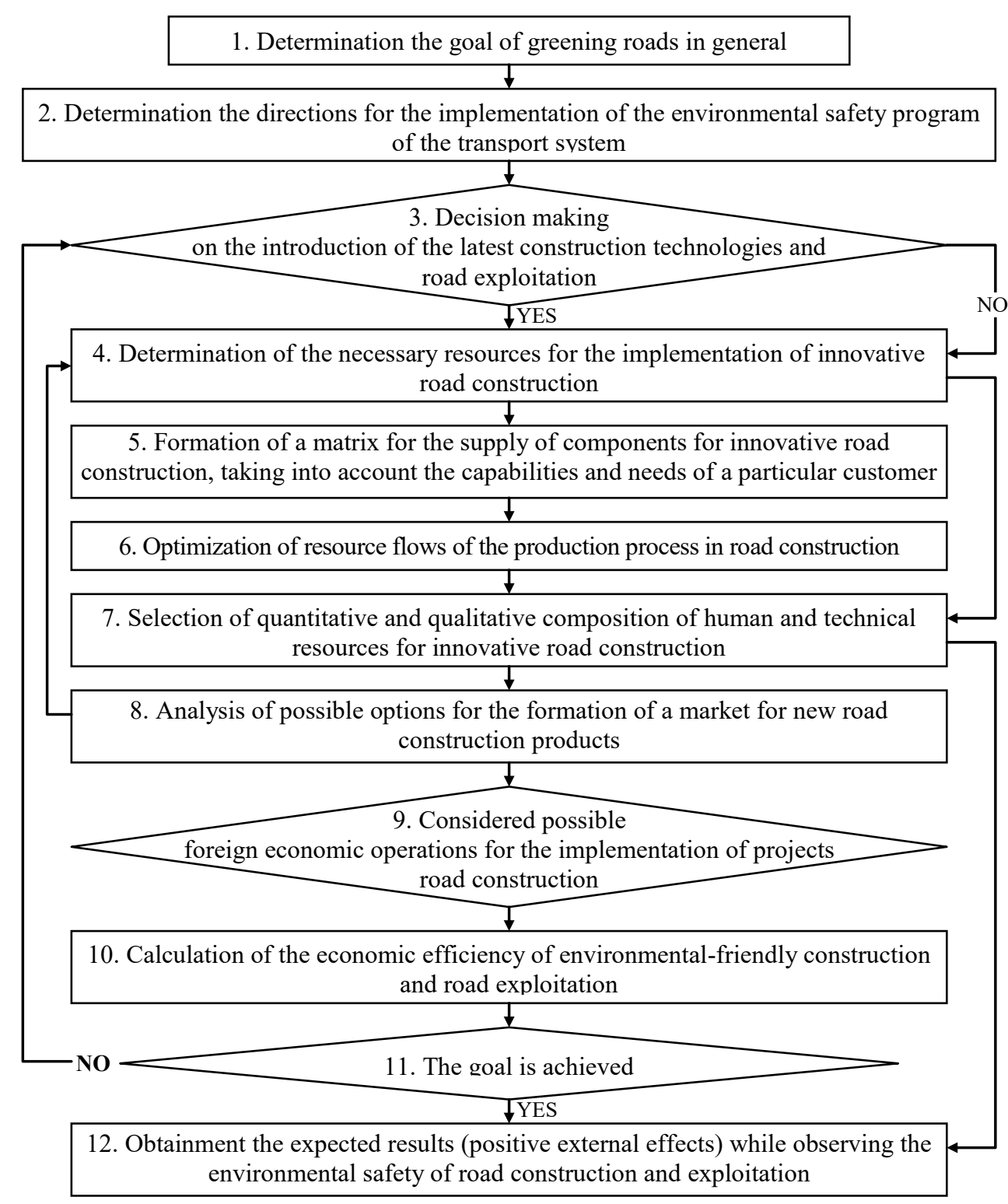

Fig. 2. Algorithm for optimizing road construction and exploitation (developed by the authors).

It should be noted that in addition to the direct impact on the environment with the results of its activities, the mining industry has an indirect, but no less notable, environmental and economic impact on it through the use of roads for the transportation of extracted minerals. There may be an environmental disruption leading to an environmental hazard. Compliance with the conditions for preserving surface from premature destruction should be a priority for the Ministry of Infrastructure and one of the main tasks of the State 
Road Agency of Ukraine and The State Service of Ukraine for Transport Safety. For this purpose, it is necessary to make appropriate amendments and additions to the environmental legislation of Ukraine.

In conditions of a decrease in the speed of movement and its termination in places of road defects, the amount of carbon monoxide emission increases several times compared with emissions at optimal speeds (about $70 \mathrm{~km} / \mathrm{h}$ ). The poor road conditions increase several times the emission of harmful substances into the atmosphere, which is an extremely adverse effect on the environment.

At the same time, taking into account the negative impact of mining enterprises on atmospheric air, including as active users of transport networks, the characteristics of this influence should be systematized (Table 5) [2].

Table 5. Characteristics of the environmental impact of the road [2].

\begin{tabular}{|c|c|c|}
\hline Environment & Factor & Characteristics of the impact on the nature \\
\hline \multirow{4}{*}{ 示 } & Cars on the road & $\begin{array}{l}\text { Air pollution as a result of exhaust emissions of the engines; } \\
\text { wear products of automobile parts and tires. Acoustic } \\
\text { pollution by traffic noise. }\end{array}$ \\
\hline & Earth roadbed & $\begin{array}{l}\text { Change in temperature, humidity, wind regime in high } \\
\text { embankments. }\end{array}$ \\
\hline & Roadbed & $\begin{array}{l}\text { Influence on the amount and composition of automobile } \\
\text { exhaust gases, the number of wear products of automobile } \\
\text { parts and tires. }\end{array}$ \\
\hline & Roads junction & $\begin{array}{l}\text { Air pollution by products of road surface wear, dust and } \\
\text { debris from its surface. }\end{array}$ \\
\hline 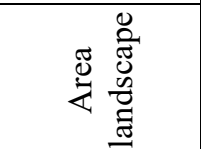 & $\begin{array}{l}\text { All engineering } \\
\text { constructions }\end{array}$ & $\begin{array}{l}\text { Seizure of land for engineering structures, quarries, } \\
\text { cavaliers, construction sites, access roads. Fragmentation of } \\
\text { the territory. Change in relief and flora. Aesthetic impact. }\end{array}$ \\
\hline \multirow{2}{*}{ 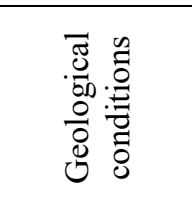 } & $\begin{array}{l}\text { Earth roadbed, } \\
\text { bridge crossings } \\
\text { and overpasses }\end{array}$ & $\begin{array}{l}\text { Deformations in the underlying soil, erosion processes of } \\
\text { the earth roadbed in adjacent areas. }\end{array}$ \\
\hline & Roadbed & $\begin{array}{l}\text { Transmission of vibration from vehicles passing to adjacent } \\
\text { areas. }\end{array}$ \\
\hline \multirow{2}{*}{ 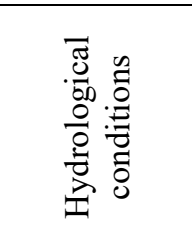 } & Earth roadbed & $\begin{array}{l}\text { Obstruction of surface water runoff, violation of } \\
\text { groundwater flow regime, drainage or waterlogging of } \\
\text { roadside areas before waterlogging. }\end{array}$ \\
\hline & $\begin{array}{l}\text { Culverts and } \\
\text { drainage } \\
\text { facilities }\end{array}$ & $\begin{array}{l}\text { Erosion of the channels of watercourses, outlet channels and } \\
\text { the formation of ravines. }\end{array}$ \\
\hline \multirow{3}{*}{$\begin{array}{l}\overline{0} \\
\text { in }\end{array}$} & Earth roadbed & Flooding of the territory from the top. \\
\hline & Roadbed & Soil pollution by earth roadbed erosion products. \\
\hline & $\begin{array}{l}\text { Infrastructure } \\
\text { constructions }\end{array}$ & $\begin{array}{l}\text { Contamination by road wear products, materials used in } \\
\text { winter road maintenance. }\end{array}$ \\
\hline \multirow{4}{*}{ 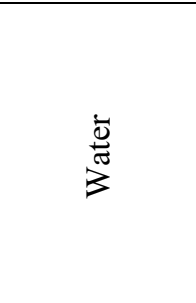 } & Earth roadbed & Pollution by garbage, household waste, oil products. \\
\hline & Roadbed & Water pollution of rivers and lakes by land erosion products. \\
\hline & $\begin{array}{l}\text { Culverts and } \\
\text { drainage } \\
\text { facilities }\end{array}$ & $\begin{array}{l}\text { Water pollution by wear products of road pavement, car } \\
\text { tires, emissions from automobiles. }\end{array}$ \\
\hline & $\begin{array}{l}\text { Infrastructure } \\
\text { constructions }\end{array}$ & $\begin{array}{l}\text { Change in the regime of water flow in watercourses (flow } \\
\text { velocity, sediment, erosion, the turbidity of the water). }\end{array}$ \\
\hline
\end{tabular}


Improving the quality of the road network can play a significant role in improving the environment. So, according to scientists, the excessive consumption of fuel per $100 \mathrm{~km}$ of the ZIL-130 truck on the primer is 17 liters, which is higher compared to driving on a road with a capital coverage, which accordingly increases the number of harmful emissions.

The actual values of indicators of the ecological state of the road are established on the basis of engineering and environmental studies (conducted during the design of roads in accordance with the requirements of DBN A.2.2-1-2003) when diagnosing the condition of the road, according to the results of environmental certification of the road [10].

An environmental offense is characterized primarily by such features as an environmental orientation, environmental wrongfulness. The essence of the environmental orientation of the offense lies in the fact that the behavior of the offender is aimed at negative changes in the state of the environment, violation of the legal regime of natural resources. Environmental danger includes not only the probability of violation of the environmental interests of society but also an increased danger to existing environmental relations in the ecosystems themselves and outside them [9].

We consider that the following can become an economic tool for the formation of the environmental safety of transport networks of the mining industry:

- economic sanctions for violation of environmental laws;

- compensation payments for damage caused to the state of the environment;

- insurance premiums for reimbursement of environmental and economic damage (environmental insurance) [2].

Forms of compensation for environmental damage may be different. First of all, if possible, it is advisable to apply damages in kind, when the offender must eliminate the negative consequences of his illegal actions (plant a forest, carry out land restoration, etc.). If this method is unacceptable, the violator is obliged to compensate for the losses incurred, the calculation of which in environmental law has its own peculiarities, since if the damage is caused to natural objects, it is not always possible to determine the real damage, the main burden in their maintenance belongs to the unearned income and benefits; a significant place is taken by the costs of restoration, improvement of the natural environment.

\section{Conclusions}

It is shown that the characteristic of the mining industry is the intensity of the impact on the natural environment, which inevitably leads to its change.

We consider that systematic information provision should promote awareness of mining enterprises, as consumers of road services, regarding the quality of natural resources of ecosystems, road products and will increase their competitiveness.

It is established that the integration of environmental and economic interests of business entities dictates the development of new fundamental approaches to the organizational and economic mechanism to support the environmental safety of the road sector.

We introduced the term "road fatigue" and calculated the fatigue coefficient. The increase in the "fatigue" of Ukrainian roads (over-design load) leads to the destruction of not only their roadbed, but also the foundation.

\section{References}

1. The Law of Ukraine "On National Security of Ukraine" of 21.06.2018. No. 2469-VIII. (2020). Retrieved from: https://kodeksy.com.ua/download.php?id=2867

2. Yurchenko, O.V. (2017). Formation of organizational and economic mechanism for ensuring the ecological safety of the road industry: diss. of a candidate of economic 
sciences: 08.00.06 - economics of nature management and environmental protection. Sumy

3. W. Dermawan, C. Vieri, P.G.B. Alam. Central European Journal of International \& Security Studies, 4, 191-207 (2019)

4. J. Barnett. Companion to Environmental Studies, 191, 188-191 (2018)

5. J. Busby. Environmental security, The Oxford Handbook of International Security. DOI: 10.1093/oxfordhb/9780198777854.013.31

6. State Statistics Committee of Ukraine, 1998-2019. Retrieved from: http://www.ukrstat.gov.ua/operative/operativ2019/tr/pv_avt/pv_avt_u/pv_avt12m19_u. htm

7. Council Directive 96/53/EC of 07.25.1996 "On the establishment for certain land vehicles moving within the Community of the maximum permitted dimensions during national and international transport and the maximum permitted weight during international transport". Retrieve from: https://auto.24tv.ua/tag/zakonodavstvo_tag73/

8. V.I. Barteneva, E.N. Glazunova. Promotion of international development. Lecture Course (The World Bank, 2012)

9. O.O. Veklich. (2003). Economic mechanism of environmental regulation in Ukraine. Kyiv: Ukrainian Institute for Environmental and Resource Studies

10. DBN A.2.2-1-2003. (2004). Composition and content of environmental impact assessment materials for the design and construction of enterprises, units and structures. Kyiv: State Construction Committee of Ukraine 